\title{
Rafael Lomeu Gomes* \\ Family multilingualism from a southern perspective: Language ideologies and practices of Brazilian parents in Norway
}

\author{
https://doi.org/10.1515/multi-2019-0080
}

\begin{abstract}
This article derives from a three-year ethnographic project carried out in Norway focusing on language practices of Brazilian families raising their children multilingually. Analyses of interview data with two Brazilian parents demonstrate the relevance of examining intersectionally the participants' orientation to categorisations such as social class, gender, and race/ethnicity. Additionally, I explore how parents make sense of their transnational, multilingual experiences, and the extent to which these experiences inform the language-related decisions they make in the home. Advancing family multilingualism research in a novel direction, I employ a southern perspective as an analytical position that: (i) assumes the situatedness of knowledge production; (ii) aims at increasing social and epistemic justice; (iii) opposes the dominance of Western-centric epistemologies; and (iv) sees the global South as a political location, not necessarily geographic, but with many overlaps. Finally, I draw on the notions of intercultural translation and equivocation to discuss the intercultural encounters parents reported. The overarching argument of this article is that forging a southern perspective from which to analyse parental language practices and beliefs offers a theoretical framework that can better address the issues engendered by parents engaged in South-North transnational, multilingual practices.
\end{abstract}

Keywords: family multilingualism, family language policy, southern perspective

\section{Introduction}

The new directions explored by recent family language policy (FLP) studies have shed light on language practices taking place in under-examined geographical locations, where different family constellations use languages beyond the more

*Corresponding author: Rafael Lomeu Gomes: Department of Linguistics and Scandinavian Studies, MultiLing - Center for Multilingualism in Society Across the Lifespan (University of Oslo), Blindern, Oslo, 0317, Norway, E-mail: r.l.gomes@iln.uio.no, rlg1984@gmail.com 
commonly studied Germanic and Romance languages (Curdt-Christiansen 2018; King 2016; King and Lanza 2019; Lanza and Lomeu Gomes 2020; Lomeu Gomes 2018; Smith-Christmas 2017). Yet, this subfield has reproduced a substantial limitation present more generally in sociolinguistics, namely, the over-reliance on northern voices, experiences, and epistemologies to the detriment of southern ones (Levon 2017; Milani and Lazar 2017).

Working towards redressing the lack of southern voices, experiences and epistemologies, in this article I examine the ways Brazilian parents make sense of their transnational and multilingual experiences in Norway, and the language ideologies that inform their language practices in the home. In doing so, my goal is to take family multilingualism into novel empirical and theoretical directions.

Feeding into the burgeoning body of research on family multilingualism in Norway (e.g. Johnsen, forthcoming; Lanza 1997; Obojska 2019; Obojska and Purkarthofer 2018; Purkarthofer and Steien 2019), the empirical focus on Brazilian parents in Norway allows us to gain a better understanding of this understudied group of people in their South-North migration trajectories as they raise their children multilingually (for Brazilian families in the UK, see A. Souza 2010, 2015; for Latin Americans in Norway, see Pájaro 2011).

Theoretically, I emphasise the relevance of unveiling the connections between the lived experiences of parents in intercultural encounters and broader social, cultural, economic, and political processes from a southern perspective. This gives us a more nuanced understanding of the language ideologies and practices of multilingual families, particularly those engaged in South-North migration. More specifically, in this article my interests lie in understanding:

- how Brazilian parents make sense of their transnational, multilingual experiences in Norway, and

- what discourses inform parental language practices in the home as they raise their children multilingually.

While these foci resonate with current research on family multilingualism (e.g. Curdt-Christiansen 2016; Moustaoui Srhir 2019; Soler and Roberts 2019), I argue that an express engagement with epistemological and ontological assumptions akin to a southern perspective (e.g. Castro-Gómez and Grosfoguel 2007; Connell 2007; Mignolo and Walsh 2018; Santos 2014, 2018) opens up the field of FLP in ways that incorporate into its agenda issues and discussions that remain untapped by current literature. More precisely, the overarching claim put forth in this article is that a southern perspective allows us to understand the racialised structures of inequality that the participants have to navigate in their daily lives; to incorporate 
the intersectional dynamics of social class, gender and race/ethnicity into analyses of language ideologies and practices of families; and to examine the historical links between contemporary language ideologies and practices, and social hierarchisations that date back to colonial times.

In the following, I first present contextual information about Brazilians in Norway. Subsequently, I discuss how family multilingualism research has been carried out within the Eurocentric canon of knowledge production in the past two decades. Then I describe the data generation and analysis processes and discuss my locus of enunciation. In the analysis, I examine data from interviews with two Brazilian mothers living in Norway. Before presenting some concluding thoughts, I discuss how this particular case can contribute to family multilingualism research more broadly.

\section{Brazilians in Norway: South-North entanglements}

The South-North migration trajectories experienced by the participants in this study are part of a broader flow of people. Considering the scarcity of published studies about Brazilians in Norway, it is worth scrutinising the discourses about each country that circulate in the media. On the one hand, it is not uncommon for Norway to be portrayed by Brazilian and international media outlets as the happiest country to live in (Borenstein and Keyton 2017). A solid welfare system that grants free access to healthcare and education, high salaries, and policies to promote gender equality are usually some of the characteristics highlighted in representations of Norway. On the other hand, Brazil has regularly been represented as one of the countries with the greatest gaps between the richest and the poorest in the world (Canzian et al. 2019) where the public healthcare and education systems are deficient, violence marks the lives of many, especially black, male youth, and corruption scandals involving politicians have been very frequent in the past few years (for more on inequality in Brazil, see Arretche 2018 and Schwarcz 2019). The warmth and resilience of its more than 200 million people, great achievements in football, the flair of samba dancers, especially women, and its delicious and varied cuisine give less distasteful tinges to some representations of Brazil in the media and possibly populate the imaginary of people across the globe. Fundamental to the overarching argument presented here is that these representations are deeply rooted in histories of colonialism. And if we want to better understand how these representations and histories are interlocked in the lived experiences of people engaged in South-North migration, a suitable 
framework is needed. Inspired by and feeding into similar endeavours (Heugh and Stroud 2019; Milani and Lazar 2017; Pennycook and Makoni 2020; L. M. T. Souza 2019), a potential alternative is the southern perspective employed here.

The stereotypical generalisations mentioned in the media representations above could be - and in fact are, as I demonstrate - made relevant in the ways participants make sense of themselves (and are perceived) as immigrants in Norway. In particular, the cases in this article speak to processes of exclusion similar to those discussed by Goffman (1963: 139) in relation to how stigmatisation of certain ethnic/racial groups serves as a way of keeping them from "various avenues of competition".

Focussing on a certain group of immigrants based on their nationality, however, brings about certain methodological issues. One of these issues relates to how the category immigrant is defined. For example, Statistics Norway (2019) has six different immigrant categories, as shown in Table 1 (adapted from Statistics Norway 2019).

Table 1: Brazilians in Norway.

\begin{tabular}{lr}
\hline Born in Norway to Norwegian-born parents & 559 \\
Immigrants & 5,042 \\
Norwegian-born to immigrant parents & 309 \\
Foreign-born with one Norwegian-born parent & 608 \\
Norwegian-born with one foreign-born parent & 3,077 \\
Foreign-born to Norwegian-born parents & 529 \\
Total & 10,124 \\
\hline
\end{tabular}

A related (and not less problematic) issue is that dealing with such fixed categorisations risks essentialising national identities in ways that do not correspond to one's self-identification. Furthermore, official data usually fail to consider those whose migratory status does not conform to national immigration laws. Based on the criteria employed in the categorisation of Table 1 (i.e. country of birth and nationality of parents), the mothers in this study would belong to the group of 5,042 people (i.e. born in Brazil to non-Norwegian parents), while their daughters would belong to the group of 3,077 people (i.e. Norwegian-born with one foreign-born parent).

Moreover, the gender differentiation available in official data is also bound by a binary understanding of gender. For instance, within the "immigrants" category (i.e. 5,042), the dichotomic division between males and females (roughly 25 and $75 \%$, respectively) overlooks the need to consider a fuller spectrum of gender and sexuality identities and expressions, mirroring a current limitation of FLP studies (King 2016). 
With these remarks in place, the understanding of national identity employed here is motivated by Alcoff's (2005: 42) more general definition of identities as "positioned or located lived experiences in which both individuals and groups work to construct meaning in relation to historical experience and historical narratives”.

One of the few publications about Brazilians in Norway is Horst, Pereira and Sheringham's (2016) study on the role of social class as a factor to account for the incentive or inhibition of further migration of Brazilians to Norway. Combining quantitative and qualitative methods, they demonstrate that there are two main reasons for Brazilians to migrate to Norway: family reunification and work. Moreover, among Brazilians in Norway, there seems to circulate an idea that women from the poorest areas in Brazil migrate to Norway through family reunification once they marry Norwegian men; whereas middle class professionals come from wealthier regions in Brazil and migrate due to work (Horst et al. 2016).

Another case in point is Zapponi's (2015) investigation of psychological constructs such as motivation and expectation as they relate to the migration experiences of Brazilian women in Norway. Drawing on the analysis of narratives elicited through semi-structured interviews, she claims that having access to the Norwegian welfare system had a positive impact on the participants' adaptation process.

The findings of these two studies serve as good entry points to start an investigation about the intersection of class and gender in the examination of the lived experiences of Brazilians raising their children multilingually in Norway. Family multilingualism research has already considered the pertinence of these social categorisations in examinations of the language practices of families. Yet, its theoretical apparatus has been fundamentally limited in that it either conceals its ontological underpinnings or draws largely on Eurocentric ways of conceptualising social reality, as I discuss below.

\section{Family multilingualism within the Eurocentric canon}

In one of the pioneering childhood bilingualism studies focussing on parents' perspectives and expectations regarding their children's upbringing, Piller (2001) examined the choices parents made in relation to what languages to use in the home, the ideologies that informed these choices, and how they were put into practice. She Piller (2001: 61) pointed out that parents who make careful choices about what languages to use in the home are particularly "elite bilinguals", 
highlighting the relevance of social class as an analytical construct to investigate family multilingualism.

Expanding Piller's (2001) findings, King and Fogle (2006) claim that such careful planning is not a phenomenon restricted to the elite as many of the participants in their research belonged to the middle class. In this study, I follow King and Fogle's (2006) proposition that parents evaluate information from external sources against their personal beliefs, and suggest that, in order to better understand the language practices of transnational parents engaged in raising children multilingually, it is crucial to also examine the experiences of these parents in intercultural encounters as they make sense of their transnational trajectories.

Similarly, Curdt-Christiansen (2009) examined the circulating ideologies drawn upon by Chinese families in Canada. Among her findings, CurdtChristiansen highlights the relevance of parents' educational expectations for the development of family language policies. Curdt-Christiansen (2009: 353) asserts that more attention should be paid to the role of social factors on the ways in which parents think about literacy and language and define their literacy and language practices: "there are various forces and contexts in society that will exert influence on family language ideologies and practices and may give rise to different language agendas”.

High educational expectations and aspirations of parents are also noted by Kirsch (2012) in her investigation of Luxembourgish multilingual mothers raising their children in Great Britain. Kirsch (2012) contrasts the circulating discourses about multilingualism in Luxembourg, where the use of more than two languages is highly valued, with the prevailing discourses in England, where a monolingual ideology is more salient. Kirsch (2012) finds that the mothers demonstrated willingness to promote the acquisition of Luxembourgish by their children. However, the mothers themselves felt pressured to be integrated into British cultural practices, which ended up being reflected in the more frequent use of English in interactions with their children.

In general, these studies have highlighted the relevance of in-depth examinations of how parents (re)appropriate circulating discourses about language and culture as they make sense of themselves and raise their children multilingually. Particularly, they have stressed the importance of categorisations such as social class (e.g. level of education of parents, aspirations for social mobility) and gender (e.g. mainly mothers have been interviewed) in better understanding the relations between language practices and ideologies in the home and broader social, cultural, economic, and political processes. Nonetheless, the theoretical frameworks that anchor the analysts' understandings and operationalisation of such categorisations (i.e. social class and gender) are left unclear. In some respects, this shortcoming seems to substantiate what drives Block (2014) to call for a social turn 
in a related discipline, namely, applied linguistics. Taking a social turn to study language-related phenomena would mean "including in one's work substantial and sustained discussions of key constructs and frameworks based on readings in the social sciences. This, as opposed to just a passing mention and/or a brief gloss of these key constructs and frameworks before moving onto research" (Block 2014:15). Engaging with theoretical advancements in the humanities is also advocated for by McNamara (2015). While language studies can benefit greatly from answering these calls, the dialogues proposed by these authors are markedly restricted to engaging with developments of canonic Eurocentric critical literature. For example, a Marxian critique of political economy, a Bourdieusian approach to class and habitus, or an intersectional approach centred around social class (i.e. Block 2014; Block and Corona 2014); and a poststructural critique influenced by (but not only) Derrida (i.e. McNamara 2015).

Turning this discussion to the examination of family multilingualism literature, in her interdisciplinary conceptual framework of FLP, for example, CurdtChristiansen (2018) appropriately calls attention to how processes taking place in the sociolinguistic, sociocultural, socioeconomic, and sociopolitical contexts exert influence on (and are influenced by) language practices in the home through the mediation of language. An aspect of this framework that could benefit from further attention is the ontological and epistemological underpinnings of these broader social, cultural, economic, and political processes. Thus, the southern perspective employed here moves in this direction by drawing on social theory to provide a theoretical anchoring for analyses of social reality; also, it exposes the imbalance between northern and southern perspectives in family multilingualism research.

Furthermore, it builds on an ongoing discussion about the epistemological and ontological limitations of Eurocentric critical thought. For example, Latin American scholars involved with the decolonial turn (e.g. Castro-Gómez and Grosfoguel 2007) suggest that frameworks aiming at discussing social, cultural, and epistemic inequalities, and economic-political relations between the centres and peripheries would be severely limited unless they attend to the historical links between the European colonisation in Latin America and hierarchisations of social categorisations such as social class, gender, and race/ethnicity.

In turn, Santos (2018) points to the affinities between conservative and critical European thought. That is, considering the contemporary levels of social and epistemic inequalities, and the global rise of political forms that are strengthened by and perpetuate these inequalities, Santos suggests that Marxian-inspired scholarship (along with other forms of scholarship) that self-identify with the label 'critical' have not been particularly successful in understanding and, more importantly, changing the world in order to diminish or end these inequalities, 
especially for those in or from the global South. An "alternative thinking of alternatives" (Santos 2018: 6) is required, he claims.

In a similar vein, Connell (2007) advocates for a kind of social science that expressly engages with knowledge produced beyond the European-American canon. She suggests that in theoretical texts in sociology, it is usually the case that ideas developed in the peripheries are exotically mentioned in passing, rather than being central to the process of theory building.

To summarise, the southern perspective employed here examines, in light of the historical links of colonialism and hierarchisations of social categorisations, how participants engaged in South-North migration make sense of their transnational trajectories and their language practices in the home. Taking a step towards increasing social and epistemic justice, it also engages with alternative ways of thinking of alternatives, without overlooking the important contributions developed in critical research the North. In doing so, it brings epistemological and ontological assumptions about social reality developed in the global South to the centre of the debate, while establishing a South-North dialogue (Kerfoot and Hyltenstam 2017; see also Coetzee 2018).

\section{Data generation, data analysis, and locus of enunciation}

This study is part of a larger, three-year ethnographic project in which I examined the language practices and ideologies of Brazilian parents raising their children multilingually in Norway. Participants were recruited via online posts on social media groups and in social events catering for Brazilians in Oslo, Norway.

Focussing on data generated in semi-structured interviews with two Brazilian mothers raising their respective child multilingually in Norway allowed me to tap into how they make sense of their transnational experiences in intercultural encounters in Norway, and their language practices in the home. The interviews covered themes such as participants' transnational practices, language beliefs and practices, and life before migrating to Norway. They took place between June and August 2017, and each lasted just over $1 \mathrm{~h}$. The names are pseudonyms and some details have been purposefully omitted to protect the participants' identity.

The audio recordings were fully transcribed and each generated a Word document containing between 10,000 and 11,000 words. Upon transcribing and listening to the recordings multiple times, certain social categorisations (i.e. social class, gender, and race/ethnicity) emerged as relevant for the present analysis. Thus, subsequently, instances where participants oriented to such categorisations 
were coded under the respective social categorisation. For example, references to education, employment, and lifestyle were coded under social class; references to social roles of men and women were coded under gender; references to skin colour, body attributes, and national and regional affiliations were coded under race/ ethnicity. This procedure was analytically helpful for it provided an overview of how salient such references were in the whole corpus.

A complicating, and illuminating, factor was that certain passages could be coded under more than one category, which is what was done. Therefore, the categories here are not conceived of as mutually exclusive. Rather, in line with an intersectional approach (Cho et al. 2013), they are understood as interconnected, hierarchical constructs traversed by complex, multi-layered relations of power.

Drawing on epistemological assumptions of discourse analysis, critical sociolinguistic, and linguistic ethnographic approaches (Copland and Creese 2015; Heller et al. 2018, Martin-Jones and Martin 2017; Pennycook 2001), I acknowledge that my social position as a Brazilian male university researcher could have influenced the participants' responses in many ways. Likewise, my social position also shapes the locus of enunciation from which I develop my analysis.

For example, attending to the reflexive nature of data generation and analysis in ethnographic research, it became clearer to me how certain aspects of my social position gained specific meanings in the interview context. I told the participants about how certain events and experiences of my life trajectory coalesced into my current research interests: e.g. moved to the United States to study English upon completing secondary education in Brazil, worked in Brazil in the field of language education for over 10 years, pursued a postgraduate degree in the UK, and a yet higher academic degree in Norway.

It could be argued, then, that education was perceived to be the main driver behind my moving to different countries, which is a somewhat sound, though certainly partial, perception. However, this perception might have also concealed my background growing up in Brazil on the blurred fringes between working class and middle class. Still, having the choice and the material means to go abroad to study is a privilege enjoyed by few who belong to the capital, cultural, and academic elites in Brazil.

This short autobiographical note about my transnational practices and socioeconomic background illustrates a few of the multiple ways my social position might have influenced participants' responses. In fact, in the next section, I point to ways it arguably did.

I move on now to analyse excerpts of interviews with each of the two focal participants to discuss (i) how they oriented to social categorisations such as social class, gender and race/ethnicity as they made sense of their transnational, multilingual experiences as Brazilians in Norway, and (ii) the language ideologies 
informing parental choices in relation to language use in the home as they raise their children multilingually.

\section{Brazilian parents in Norway: intercultural encounters and family multilingualism}

The analyses that follow do not aim at providing a snapshot of "Brazilians in Norway", as if such generic and abstract entity existed. Rather, examining the particular case of two Brazilian mothers shows precisely how such overriding categories can be problematic, but it also allows us to consider certain similarities. This is in line with Santos' (2014: 356) understanding of culture, which further motivates the ethnographic approach of this study: "Cultures are monolithic only when seen from the outside or from afar. When looked at from the inside or at close range, they are easily seen to comprise various and often conflicting versions of the same culture."

Below I present ethnographic portraits of the two focal participants, Berenice and Adriana, and analyse data excerpts where they narrate certain intercultural encounters they experienced in Norway. This is followed by analyses of data excerpts related to their children's multilingual upbringing. Their cases are particularly interesting because they reveal how two Brazilian women with different backgrounds orient to social categorisations such as social class and race/ethnicity as they navigate complex life circumstances, disputed identity positions, and multilingual language practices in Norway. Moreover, examining their cases through an intersectional approach allows us to gain a better understanding of the connections between broader social, cultural, economic, and political, and language ideologies and practices in the home.

\subsection{Intercultural encounters}

\subsubsection{Berenice: ‘No, I don’t dance samba.'}

Berenice (47) came to Norway in 2006 for a sabbatical year in which she wanted to take a Master's degree and ponder upon her life. She met her Norwegian husband, William, who was also attending a course at the Norwegian higher education institution where she studied, and they have a seven-year-old, Norwegian-born daughter, Claire. Before moving to Norway, Berenice had lived in England twice in 
the 1990s, first to study and travel, then to do an internship. She reported speaking Portuguese, Spanish, English and Norwegian.

(1) eu vivo aqui há 11 anos, e sem-e sempre tem algum episódio que, que- sim, que me julgam rapidamente pelo, né, esse estereótipo de ser brasileira. De ser por exemplo “Ah então tu dança samba.” “Não, (@@@) não danço samba.Eu sou do Sul do Brasil (@@@), a gente não sabe dançar samba, nós somos muito sem graça.” (@@) Ou, por exemplo, a própria, essa [atributo físico da pessoa referida] aqui, que é $100 \%$ norueguesa. Quando eu a conheci ela disse “Ah que legal, do Brasil, é? Ah então, mas tu já é assim norueguesa, né?” eu disse “Não. Eu já moro há 11 anos.” “Ah então tu já é norue-” "Não! Eu sou brasileira morando aqui."

I have lived here for 11 years, and al-there's always an episode where, whereyes where [they] judge me quickly for, right, this stereotype of being Brazilian. of being for example “Oh, so you dance samba.” "No, (@@@ [I] don't dance samba.I'm from Southern Brazil (@@@),we can't dance samba, we are very dull.”(@@) Or, for example, the very, this with [physical attribute of the referred person] here, who is 100\% Norwegian when I met her she said "Oh how nice, from Brazil, eh? Oh so, but you already are like Norwegian, right?” I said "No. I have lived here for 11 years". "Oh then you already are Norwe - "No! I'm Brazilian living here."

In excerpt 1 , Berenice starts off by enacting a dialogue with an imaginary interlocutor about her dancing skills. Her interlocutor assumes that, being from Brazil, she can dance samba. She squarely rebuts it and elaborates on it, relating her inability to dance samba to her place of origin (i.e. Southern Brazil).

In what follows, a shift from singular personal pronoun (I'm from Southern Brazil) to plural personal pronouns (we can't dance samba, we are very dull) takes place. This pronominal shift can be understood, at an interactional level, as a strategy employed by Berenice in order to negotiate her identity as belonging to a larger community whose members are not particularly highly-skilled in dancing samba (for the role of pronominal switches in narratives of immigrants, see De Fina 2003). Moreover, it can be argued that Berenice is attempting to deconstruct a stereotypical assumption that circulates at societal level, one that stems from an understanding of cultures as homogenous entities, namely, that Brazilians dance samba.

However, although the social categorisation race/ethnicity is not explicitly mentioned, the reference to a region of Brazil with a large concentration of white people descending from, mainly, German immigrants is made as a way to distinguish between people from Southern Brazil (dull, can't dance samba) and 
Brazilians from other regions. Interestingly, what lies behind this distinction is the reification of Brazilians from other regions, with different racial/ethnic backgrounds, as supposedly good samba dancers. Therefore, while she seems to challenge stereotypes about Brazilians in Norway (or abroad), by making a distinction between people from Southern Brazil and from other areas in Brazil, Berenice, albeit inadvertently, legitimates and reproduces these stereotypes, and distances herself from them. This illustrates how, at a discursive level, practices of differentiation based on racial/ethnic markers that originate in colonial times in Brazil linger on to this date. The intersectional links between race, gender and nationality, and the ability to dance samba have also been discussed by Melo and Ferreira (2017). In their multimodal analysis of t-shirts marketed in the occasion of the FIFA World Cup of Soccer 2014, they note that while the racialised, hypersexualised bodies of black women are discursively construed as being able to dance samba and having extraordinary skills in bed, the bodies of white women do not carry these indexical meanings.

Excerpt 2, below, immediately followed excerpt 1:

(2) e várias outras situações assim, muitas, muitas. De um- de tu ter que explicar o tempo inteiro o teu background, explicar da onde tu veio. E- e às vezes, sabe o que que eu tô fazendo? ( $\mathrm{mmm}$ ) Uma coisa que eu não- assim, eu nunca faria isso, mas eu tenho feito. É exagerar um pouco- é...assim, quase uma coisa um pouco feia assim "Olha, eu venho de uma família que tem dinheiro” (ah) ai, é super feio dizer isso (@@@@@@) “...que tem educação. Eu estudei em colégio particular. Eu estudei.” eu sei que isso parece um pouco assim elitista mas é pra eles- é porque eles, o norueguês como tem essa, essa cultura muito homogênea, ele não consegue entender essas diferenças culturais e de educação que nós temos, que eles praticamente não tem. E eles sempre botam então "Ah Brasil é terceiro mundo, é- veio pra cá pra ter uma vida melhor” sabe?(uhum) Tem muito esse - "Não, olha, eu vim de uma família que sim, que todos são advogados, tem educação. Sim, na minha casa tudo funciona direitinho."

and many other situations, like, many, many. Of a- of you have to explain all the time your background, explain where you come from. And-and sometimes, do you know what I'm doing? ( $\mathrm{mmm}$ ) One thing that I'm not - like, I'd never do this, but I have been doing it. It is to exaggerate a bit-yes... like, it's almost one thing [that's] a bit ugly, like "Look, I come from a family that has money...” (ah) oh...it’s super ugly to say this (@@@@@@ “...that has education. I studied in private school. I have studied." I know this seems a bit elitist but it's for them-it's because they, the Norwegians, since [they] have this, this very homogeneous culture, they can't understand these cultural and 
educational differences which we have, which they basically don't have. And they always put then "Oh Brazil is Third World, it's-[you've] come here to have a better life." you know? (uhum) there's a lot of this- "No, look, I come from a family that yes, they are all lawyers, have an education. Yes, at home everything works properly."

In this excerpt, Berenice suggests that intercultural encounters like the one narrated in excerpt 1 are recurring (and many other situations, like, many, many). Later on, she hesitatingly admits to saying certain things as a way to prevent her interlocutor from making erroneous assumptions about her background. The hesitance is marked by interruptions and hedges (like). Also, she seems to be in conflict with her own decision, noted in the contradiction in her explanation that what she has been doing is something that she would 'never' do. Moreover, she evaluates negatively her exaggeration when presenting herself using the term ugly, supporting the idea that she experiences a degree of conflict. This sort of hesitance, (e.g. with interruptions and hedges) has been referred to as disclaimer (Hewitt and Stokes 1975: 3), "a verbal device employed to ward off and defeat in advance doubts and negative typifications which may result from intended conduct". Additionally, it could be argued that our (perceived) shared class position and my laughter could have influenced what Berenice decided to share with me in this part of the interview.

Moreover, in her account, Berenice indicated that she feels compelled to say such, reprehensible things as a way to provide her interlocutor with a more nuanced understanding of the heterogeneity of the Brazilian society related to the distribution of wealth, in opposition to the homogeneity that allegedly characterises the Norwegian society. The use of first (we) and third (they) person plural pronouns serves as clear markers that distinguish Brazilians from Norwegians by discursively constructing Norwegians as a homogenous group.

Towards the end of this excerpt, Berenice gives another example of exchange between an imaginary Norwegian interlocutor and herself. Her interlocutor is represented as relating the socio-economic context of Brazil to Berenice's reason to migrate to Norway (to have a better life). Again, she quotes herself explicitly talking about the socio-economic status of her family and making reference to the material conditions of her Brazilian household where 'everything works properly'. Therefore, transplanting the socioeconomic stratification present in Brazil to the Norwegian context, Berenice indicates that social class and race/ethnicity are relevant social categorisations to which she orients in the negotiation of her identity in intercultural encounters in Norway. 


\subsubsection{Adriana: 'because they look at you and come to a conclusion'}

Adriana (37) came to Norway in 2013 to live with her Norwegian boyfriend (now cohabitant) Håkon, and to do a postgraduate degree (Master). They have a twoyear-old, Norwegian-born daughter, Emma. Besides Portuguese, Adriana reported speaking Norwegian, English, French, and another Germanic language. She learned the latter three languages in another European country, where she lived for more than five years before moving to Norway. At the time of the interview, Adriana was looking for a job as a school teacher.

(3) porque eles já olham pra você e tiram a conclusão, entendeu? Então eu acho que a língua é a questão geral de todas as profissões, é a primeira coisa você \#\#\#\# a língua. E como eu disse, eu acho muito difícil você ahm... ter a língua igual a eles, a gente nunca vai ter, nunca, nunca vai falar igual eles. Podemos falar muito bem, podemos falar corretamente a gramática, mas você sempre vai falhar numa palavra. E...ja em alguns casos é... é suficiente because they look at you and come to a conclusion, you know? So I think that language is the general question of all professions, it's the first thing you \#\#\#\# the language. And like I said, I think it's very difficult you erm...to have the language like them, we will never have, never, never going to speak like them. We can speak very well, we can speak the grammar correctly, but you will always fail in a word. And... ja in some cases it's... it's enough

The excerpt above begins with a reference to the close association between one's physical attributes and one's ability to speak Norwegian made by interviewers when coming in contact with job applicants for the first time. That is, Adriana, who has curly black hair, suggested that recruiters make (possibly wrong) assumptions about interviewees' proficiency in Norwegian depending on their looks, leaving behind in the hiring process immigrants (whose looks deviate from a stereotypical image of what a typical Norwegians look like). Though somewhat implicitly, Adriana orients to physical attributes related to race/ethnicity and linked to language competence. This interpretation is strengthened considering other parts of the interview. For example, Adriana mentioned how her daughter Emma greets people in Portuguese if their hair is like her mother's: 'Sometimes she sees someone like with the hair like mine and she says "Hello".

As Adriana continues, she draws on a native speaker ideology that positions Norwegians as possessors of a degree of proficiency in Norwegian unattainable to her and other immigrants. It is noteworthy, nevertheless, that Adriana reported having acquired the necessary level of knowledge of Norwegian to work as a school teacher after living in Norway for two years. Moreover, while still talking about job 
recruitment processes, Adriana suggested that having connections was crucial for a positive outcome in the selection process: 'Yes, unfortunately it's like this. You only get a job if you know someone'.

In sum, in reflecting upon her multilingual experiences in the Norwegian labour market context, Adriana presented three interconnected factors that might hold immigrants back in relation to Norwegian job applicants: knowledge of Norwegian, networks, and physical attributes. In a sharp analysis of the intricate relationships between language competence and performativity of selves in job interviews, Pájaro (2018) proposes that the resources that are valued in the Norwegian labour market are not evenly distributed among different speakers. Adriana's case supports the idea that, despite having sufficient knowledge of Norwegian according to what is formally required, in the job interview context, this resource is not accessible to her because of her looks. In fact, her case draws attention to how physical attributes linked to race/ethnicity may not only play a role in recruitment decisions, but also gain more weight than other supposedly objective criteria such as language proficiency attested by standardised exams.

(4) Pra mim é bom, porque eu...eu não tenho a vida de imigrante. A maioria dos imigrantes, vamos falar a verdade, tem a vida mais difícil. Você tem que trabalhar, você tem que fazer isso...eu tenho sorte, entendeu. Eu tenho sorte, tenho uma vida mais, melhor, então, eu não tenho problema, né. \#\#\# arrumo um trabalho...tanto que eu pude esperar todo esse tempo pra poder arrumar um trabalho que eu quero. Então, pra mim a adaptação não é, não foi tão difícil. Tenho família, a gente faz esqui...então eu levo a vida igual... os noruegueses

It's good for me, because I... I don't have the immigrant life. Most immigrants, let's speak the truth, have a harder life. You have to work, you have to do this... I'm lucky, got it. I'm lucky, I have a more ... better life, so, I have no problem, right. \#\#\# get a job... so much so that I could wait all this time to get the job I want. So, for me the adaptation is not, wasn't difficult. I have a family, we go skiing...so I live a life like...the Norwegians

In excerpt 3, Adriana sees herself as being at a disadvantage in relation to Norwegians when looking for a job and, thus, aligns herself with other immigrants. Interestingly, when talking about her adaptation process upon migrating to Norway (excerpt 4), Adriana positions herself in alignment with Norwegians and in disalignment with immigrants. She acknowledges that her privileged position ('I'm lucky', 'I have a more... better life') distinguishes her from other immigrants, who 
have to work in whatever kind of employment is most readily available to them. In contrast, Adriana has had the possibility of not working until finding the job she wants as a school teacher.

Finally, Adriana made it clear in the interview that it was a combination of reasons that brought her to Norway: her relationship and her studies. Knowing that I moved to Norway to work towards my doctorate, Adriana explained 'Like you. I came to study.' This gains particular relevance when we consider the stereotypical image that circulates locally already mentioned, that is, that Brazilian women married to Norwegian men in order to move upwards socially (Horst et al. 2016).

Excerpts 1-4 are accounts of how Adriana and Berenice were perceived by their interlocutors as occupying social positions that they felt did not correspond to their own perceptions. It was evident that these participants' orientation to social categorisations such as social class, gender, and race/ethnicity was paramount in the renegotiation of their identities, be it in the interview context or in the intercultural encounters themselves.

Looking at these processes of identification from an intersectional perspective helps us to gain a better understanding. Moreover, a decolonial approach affords a suitable framework for analysing the intersection of social categorisations in the light of historical colonialism and contemporary transnational relations of global coloniality. Castro-Gómez and Grosfoguel (2007: 13, my translation) claim that "the international division of labour between centres and peripheries, as well as the ethnic-racial hierarchisation of populations, formed during the many centuries of European colonial expansion, have not been significantly transformed with the end of colonialism and the formation of nation states in the periphery". Put differently, the judicial-administrative independence of former colonies has not been accompanied by a significant structural change in the relations between centre and peripheries in that social hierarchisations of gender, race/ ethnicity and class are still sustained nowadays. This assumption is particularly useful to think with when we consider the South-North transnational trajectories of the participants.

\subsection{Family multilingualism: language ideologies and language practices}

As noted, language beliefs and practices in the home are influenced by parents' own lived experiences which, in turn, are connected to broader social, economic, cultural, and political processes. The southern perspective employed in the analyses in Section 5.1 helped us to scrutinise these connections as parents make sense 
of their transnational, multilingual experiences in intercultural encounters. Also, I pointed to how these broader processes are yoked to colonial histories, in that hierarchisations of class, gender and race/ethnicity have outlived the independence of former colonies, though assuming different forms. With this in mind, I now turn to an examination of the language ideologies that inform parental language practices in the home.

\subsubsection{Berenice: "And even the way of perceiving the world"}

(5) Ahmmm então eu acho que só tem vantagem. Primeiro por isso- que é uma língua que ela aprende de gra - gratuitamente. Segundo que eu acho que ela vai ter uma visão de mundo muito maior, uma f-, uma coisa de adaptação assim melhor do que as crianças que têm só uma língua. (uhum). Ahmmm eu vejo que pra ela aprender inglês é ridículo de tão rápido, também. Ermmm so I think there's only advantage. First for this- that it's a language that she learns for fre-free of charge. Second that I think she is going to have a much wider worldview, a f-, an adaptation thing that's, like, better than the children who only have one language. (uhum). Ermmm I see that for her learning English is ridiculously quick, also.

In the passage above, Berenice answers my question about the potential advantages and disadvantages of bilingualism. She notes three perceived advantages of Claire knowing more than one language from birth. The first advantage can be framed within an understanding of learning languages as an investment that would generate an asset to be capitalised on in the future; a similar view was held by parents in Curdt-Christiansen' (2009) and Piller's (2001) studies. The second suggests that knowing more than one language can influence one's worldview to the point of enabling greater adaptability. And the third points to a potential cognitive advantage afforded by learning more than one language, that is, learning two languages from birth can facilitate learning another language afterwards.

It is difficult to grasp what Berenice meant exactly by greater worldview or better adaptation. However, after mentioning that she had read that a bilingual child has greater ability to learn more languages and to learn in general, Berenice continued:

(6) E até a forma de perceber o mundo, sabe? É dife- eu vejo que é diferente, exatamente pelo fato de elas viajarem mais pra outro país $(\mathrm{mmm})$, de conviverem com crianças- com outra, em outra língua, não é? (uhum) De vivenciarem outras coisas, de comerem outra comida, de brincarem de outra forma (mmm). 
And even the way of perceiving the world, [you] know? It's diffe-I see that it's different, exactly by the fact that they travel more to another country ( $\mathrm{mmm}$ ), that they live with children- with another, with another language, isn't it? (uhum) That [they] live other things, eat other food, play in another way (mmm).

It becomes clearer now what was meant by greater worldview and better adaptation. It seems Berenice believes that being bilingual yields the possibility of experiencing alterity or 'otherness': going to another country, playing different games, eating different food, and being with others. However, it is not only a matter of doing different things, but rather doing different things differently. What Berenice seems to be getting at is that multilingualism enables her daughter to be more culturally aware and acceptant of diversity, a sort of a lay version of linguistic relativism: knowing one language influences how one perceives the world; knowing multiple languages allows one to perceive the world in multiple ways. Kirsch (2012) also found this to be a belief about advantages of bilingualism reported by a mother.

As we have seen, in excerpt 2, Berenice suggests that the lack of appreciation of her interlocutor for the heterogeneity present in Brazil was motivated by the alleged homogeneity present in the Norwegian culture. Raising Claire to have Portuguese in her repertoire could then be seen as a way of giving her the resources needed to perceive the world differently, and, thus, be appreciative of cultural differences.

Additionally, appreciating cultural differences, knowing multiple languages, and travelling to different countries can be conceived of as socialising practices that constitute a cosmopolitan class habitus, a distinctive trait of the Brazilian upper classes (Pulici 2014).

In sum, analysing Berenice's beliefs about multilingualism illustrated in excerpts 5 and 6 against the backdrop of the ways in which Berenice negotiates her social position in intercultural encounters in Norway as belonging to the Brazilian upper classes (i.e. excerpts 1 and 2) can be useful for two interrelated reasons. First, it helps us to unpack the possible connections between a cosmopolitan class habitus valued by the Brazilian upper classes and Berenice's beliefs about multilingualism. Second, by socialising Claire into into and through multilingual language practices (cf. Schieffelin and Ochs 1986), Berenice discursively constructs conditions for the reproduction of what is considered to be socially and culturally appropriate for her class position. After all, within a language socialisation tradition, language can be understood as: "the primary symbolic medium through which cultural knowledge is communicated and instantiated, negotiated and 
contested, reproduced and transformed" (Garrett and Baquedano-López 2002: 339).

\subsubsection{Adriana: "I see how good it is to speak many languages"}

(7) Eu acho que é natural. Eu acho que falar a minha língua é natural eu falar- eu sei ela, ela entende, entendeu. Mas, eu acho que é importante. E pra ela é bom, porque eu vejo como é bom falar várias línguas e se eu falo com ela é uma coisa simplesmente de graça pra ela. Que ela vai aprender. Então- mas assim eu acho que é natural falar sua língua.

I think it's natural. I think that speaking my language is natural for me to speak-I know she, she understands, you see. But I think it's important. And for her it's good, because I see how good it is to speak many languages and if I speak to her it's something completely free for her. That she will learn. So-but like I think it's natural to speak one's language.

The passage above suggests that Adriana bases her beliefs about multilingualism and her language practices in the home on her own life experiences. For example, elsewhere she talked about how knowing English, the language of instruction of her master's degree, was crucial to her decision to move to Norway: "If I didn't know English I wouldn't have done the master's here". In addition, a fuller picture of Adriana's language beliefs and practices cannot disregard the discriminatory situations in recruitment processes she reported having experienced. That is, in excerpt 3, Adriana provided an account of her experiences of being to job interviews where the recruiters seemed to draw wrong conclusions about her proficiency in Norwegian because of her physical traits (i.e. because they look at you and come to a conclusion, you know?). So, when Adriana says she can pass on Portuguese to Emma at no cost just by speaking it to her (i.e. excerpt 7), it is relevant to consider how Adriana experienced the negative outcome of assumptions that correlate physical traits to language proficiency. Therefore, not only does it feel natural for Adriana to speak Portuguese to Emma, but doing so would also benefit Emma in the future, potentially in the labour market too.

In a similar vein, when I asked her about the possible advantages and disadvantages of bilingualism, Adriana commented "I think that not knowing languages deprives you of opportunities". Interestingly, the main reason Adriana gave for learning Norwegian was her pregnancy. Learning Norwegian was not a priority upon her arrival, for she was focussing on her postgraduate studies in English. However, when Adriana knew she was 
pregnant, she reported to have thought "Now I have to learn, right? Having a child who speaks a language I don't know...no, for me that won't work”. This is in consonance with findings of previous studies, that have suggested that becoming a parent or imagining future parenthood can have important consequences for language practices in the home (Pujolar and Gonzàlez 2013; Purkarthofer 2019).

The analysis of the excerpts of the interview with Adriana taps into interesting aspects related to the ways in which she makes sense of her transnational, multilingual self and her beliefs about multilingual upbringing. Adriana's reported experiences in job interviews suggest that the value in the Norwegian job market associated with being proficient in Norwegian will never be accessible to her because her language skills are bound to be evaluated in conjunction with her physical traits, which index her 'non-Norwegianess'. Moreover, Adriana seems to be comfortable with the idea that, growing up in Norway, Emma is going to learn Norwegian anyway. While becoming pregnant with Emma seems to have motivated Adriana to learn Norwegian, passing on Portuguese to her daughter "completely free" could give Emma a head start in a job market where knowing languages well is a requirement. This would be especially the case if they were to move to Brazil, a possibility Adriana had not ruled out. In sum, analysis of the excerpts above emphasise that, in order to get a fuller picture of the languages Adriana uses with Emma and the reasons supporting her choices, it is important to take in consideration both Adriana's lived experiences in intercultural encounters in Norway and her plans for the future.

In this subsection, I analysed data excerpts in which parents talked about their language practices in the home, revealing certain language beliefs that they seemed to hold. As I hope it has become clear, I do not expect to draw causal relationships between the ways Brazilian parents make sense of themselves based on intercultural encounters they reported having with their language practices in the home. Yet, in line with the studies reviewed above, I underline the importance of scrutinising the social, cultural, economic, and political processes relevant to parents' lives in order to better understand how they make sense of themselves as members of multilingual families raising their children multilingually. My overarching claim has been that carrying out this endeavour from a southern perspective elucidates a set of problematics that has not been attended to in family multilingualism research. Elsewhere, I provide a detailed analysis of the interactions between Adriana, Emma and Håkon and point to the ways in which national affiliations are negotiated in multilingual language practices in the home (Lomeu Gomes 2020). In the section below I elaborate on what I mean by a southern perspective and sketch out its potential contributions to family multilingualism research. 


\section{Contributions of a southern perspective to family multilingualism}

Family multilingualism research has been limited in reach because of its Eurocentric bias (Smith-Christmas 2017). I suggest that an important part of addressing this limitation entails examining critically the epistemological tenets upon which current family multilingualism research draws, as well as its implications. This section is also an attempt to answer the call put forth by Block (2014) and McNamara (2015) in relation to the need for engaging more thoroughly with theoretical discussions in language-related studies.

A helpful epistemological stance in the endeavour mentioned above can be that taken by Castro-Gómez (2007) who, in the context of decolonising the university in Latin America, proposes the notion of hubris of the zero point: an epistemological model which presumes the objectivity of the place from which the analyst produces knowledge (i.e. the zero point). A similar discussion is proposed by L. M. T. Souza (2019) in his analysis of theoretical developments in applied and sociolinguistics related to recent conceptualisations of language that do not acknowledge the locus of enunciation as a fundamental aspect of theory building. In dialogue with these positions, I suggest that taking a southern perspective is a way of addressing this current limitation in family multilingualism research.

Drawing on epistemological assumptions of southern theory (Connell 2007), epistemologies of the South (Santos 2014, 2018), and decoloniality (Castro-Gómez and Grosfoguel 2007; Mignolo and Walsh 2018) the southern perspective proposed here is an analytical position that: (i) assumes the situatedness of knowledge production; (ii) aims at increasing social and epistemic justice; (iii) opposes the dominance of Western-centric epistemologies; (iv) sees the global South as a political location, not necessarily geographic, but with many overlaps.

Like the participants in this study, my life trajectory has also been marked by South-North migrations and it is undeniable that these experiences have shaped my current research interests.

Moreover, a Southern body trained in academic institutions in the global North permits me to inhabit a locus of enunciation that resembles Anzaldúa's (1987) borderlands, a location of border culture where border thinking (Mignolo 2000) takes place. As such, in this article I have attempted to put forward a South-North dialogue in a critical sociolinguistic vein, expressly engaging with epistemological assumptions present in the theorising done by scholars from the global South, while also employing concepts developed in Northern contexts.

More specifically, conceptualising intercultural encounters as events where intercultural translation takes place allows us to conceive of them as sites for 
reaching cultural understandings that acknowledge differences. Santos maintains that intercultural translation

consists of searching for isomorphic concerns and underlying assumptions among cultures, identifying differences and similarities, and developing, whenever appropriate, new hybrid forms of cultural understanding and intercommunication that may be useful in favoring interactions and strengthening alliances among social movements fighting, in different cultural contexts, against capitalism, colonialism, and patriarchy and for social justice, human dignity, or human decency (Santos 2014: 212).

While Santos (2018) highlights the collective dimension of intercultural translation as a tool that allows for different social movements to share experiences that might be mutually beneficial in their struggles against different forms of oppression, I explore it at an individual dimension as persons from different cultures come together in mundane encounters. However, the work of intercultural translation does not imply completeness or finitude as if a static culture A would find in its particular, predefined sets of practices and ideas expressions that could be perfectly transposed into culture B, matching culture's B respective sets of practices and ideas. Rather "[t]ranslation [...] implies incompleteness and ignorance and the need to overcome both; translation refers also to the fact that overcoming both of these in order to attain the desire of completeness is beyond realization." (L. M. T. Souza 2019: 20).

Similarly, Viveiros de Castro (2004) characterises the work of translation as essentially marked by equivocation. This is not an understanding of translation as a practice that is doomed to failure. Rather, what should be envisioned as a premise of translation is, in fact, the realisation that communication by differences is possible. Arguing that equivocation is at the foundation of relations, Viveiros de Castro (2004: 10) proposes that: "[t]o translate is to presume that an equivocation always exists; it is to communicate by differences, instead of silencing the Other by presuming a univocality - the essential similarity-between what the Other and We are saying”.

In sum, combining the notions of intercultural translation (Santos 2014) and equivocation (Viveiros de Castro 2004) opens up the possibility of conceiving of intercultural encounters taking place in contact zones (see Pratt 1991) where different cultures meet. Importantly, these notions espouse an understanding of culture as dynamic, complex and marked by heterogeneity. While these ideas would not sound too unfamiliar to family multilingualism scholars working with ethnographic approaches, the southern perspective I propose here gives adequate theoretical grounding to the analysis and shifts the power/knowledge imbalance of contemporary sociolinguistic research. 


\section{Conclusion}

The South-North entanglements illustrated by the migration trajectories examined in this study pose questions that have underpinned the endeavour undertaken here:

- How do the Brazilian histories of colonialism influence the continuous structural reproduction of inequality in contemporary migratory flows?

- In what ways do power relations at the intersection of social class, gender, and race/ethnicity operate in the participants' account of intercultural encounters in Norway?

- How does the lived experience of Brazilian parents abroad shape their language beliefs and language practices in the home?

I suggest that a southern perspective gives a suitable theoretical anchoring for the particular kinds of questions thrown up by the South-North entanglements analysed here. That is, a southern perspective on family multilingualism is particularly relevant to the analysis of the experiences of Brazilians in Norway because, following Castro-Gómez and Grosfoguel (2007), it considers that despite having gained independence at a political level, the hierarchical economic and cultural relations between centres and peripheries have not been significantly transformed with the end of colonialism. Also, it perceives the complex interweaving of power relations that reifies hierarchies of social class, gender, and race/ethnicity. Finally, in trying to unveil the forces that operate in transnational migration flows between central and peripheral countries, it gives equal footing (unlike Marxian Worldsystem analyses in general, and most Anglo-Saxon postcolonial approaches) to the political economic dimension of the material relations of production, and to the symbolic, discursive realm where these relations gain meaning (Castro-Gómez and Grosfoguel 2007).

The studies reviewed here underlined the importance of scrutinising the social, cultural, economic, and political processes relevant to parents' lives in order to better understand how they make sense of themselves as members of multilingual families raising their children multilingually. In Section 5, I explored how parents made sense of their transnational, multilingual experiences in intercultural encounters in Norway. As noted, the participants reported experiencing conflicting situations in which their interlocutors positioned them in places they felt did not capture well their complex social positions. Attending to their orientations to social categorisations such as social class, gender, and race/ethnicity from an intersectional perspective was crucial to the building of a better understanding of how power relations - that encompass social, cultural, economic, and 
political dimensions - between centre and periphery are discursively reproduced and challenged in intercultural encounters.

In conclusion, drawing on a decolonial approach, the southern perspective proposed here reveals how hierarchisations of social categorisations present in the Brazilian context are transplanted in complex ways into the Norwegian context as multifaceted power relations are discursively and materially reproduced and resisted. This helps us to gain a better understanding of how the broader social, cultural, economic, and political processes, particularly those relevant for those engaged in South-North migration trajectories, shape the ways parents make sense of their transnational, multilingual experiences which, in turn, influence their language practices in the home.

Acknowledgments: This work was partly supported by the Research Council of Norway through its Centres of Excellence funding scheme, project number 223265. A previous version of this paper was presented at a writing retreat organised by Jan Svennevig and Kristin Vold Lexander in Sør-Fron, Norway on 4 and 5 February, 2019. I benefited from the expert advice I received from them and from Jannis Androutsopoulos, Jessica Pedersen Belisle Hansen, and Maria Obojska on that occasion. I would also like to thank the detailed feedback on previous drafts I received from Alfonso Del Percio, Judith Purkarthofer, Christopher Stroud, and my academic supervisors Pia Lane, Elizabeth Lanza, and Alastair Pennycook. Moreover, the insightful comments from the anonymous reviewers were crucial in shaping this paper into this final version. Shortcomings and mistakes are my own. Finally, I thank Adriana and Berenice for participating in this research project.

\section{Transcription Conventions}

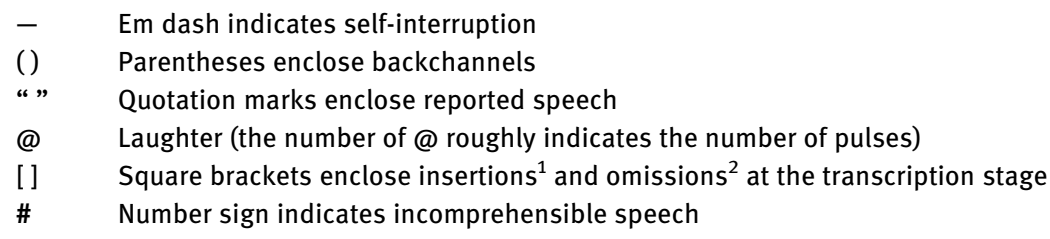

1 Portuguese is a null-subject language; subjects have been inserted in the English version of transcripts if they were dropped in the original recording.

2 In Excerpt 1, Berenice refers to a physical attribute of the person she was talking about. I chose to omit it because it is irrelevant for my analysis, but it could facilitate the identification of the referred person. 


\section{References}

Alcoff, Linda. 2005. Visible identities: Race, gender, and the self. Oxford: Oxford University Press. Anzaldúa, Gloria. 1987. Borderlands/La Frontera: The New Mestiza. San Francisco: Aunt Lute Books.

Arretche, Marta. 2018. Democracia e redução da desigualdade econômica no brasil: a inclusão dos outsiders. Revista Brasileira de Ciências Sociais 33(96). 1-23.

Block, David. 2014. Social class in applied linguistics. London: Routledge.

Block, David \& Victor Corona. 2014. Exploring class-based intersectionality. Language, Culture and Curriculum 27(1). 27-42.

Borenstein, Seth \& David Keyton. 2017. Who's happy, who's not: Norway tops list, US falls. https://apnews.com/308a9c38257f4131bee281e3c35aa6ca (accessed 19 August 2019).

Canzian, Fernando, Fernanda Mena \& Lalo de Almeida. 2019. Brazil's super-rich lead global income concentration. https://temas.folha.uol.com.br/global-inequality/brazil/brazilssuper-rich-lead-global-income-concentration.shtml (accessed 20 August 2019).

Castro-Gómez, Santiago. 2007. Decolonizar la universidad. La hybris del punto cero y el diálogo de saberes. In Santiago Castro-Gómez \& Ramón Grosfoguel (eds.), El giro decolonial:

Reflexiones para una diversidad epistémica más allá del capitalismo global, 79-91. Bogotá: Siglo del Hombre Editores.

Castro-Gómez, Santiago \& Ramón Grosfoguel (eds.). 2007. El giro decolonial: Reflexiones para una diversidad epistémica más allá del capitalismo global. Bogotá: Siglo del Hombre Editores.

Cho, Sumi, Kimberlé Williams Crenshaw \& Leslie McCall. 2013. Toward a field of intersectionality studies: Theory, applications and praxis. Signs: Journal of Women in Culture and Society 38(4). 785-810.

Coetzee, Frieda. 2018. Hy leer dit nie hier nie ('He doesn't learn it here'): Talking about children's swearing in extended families in multilingual South Africa, International Journal of Multilingualism 15(3). 291-305.

Connell, Raewyn. 2007. Southern theory: The global dynamics of knowledge in social science. Cambridge and Malden: Polity Press.

Copland, Fiona \& Angela Creese. 2015. Linguistic ethnography: Collecting, analysing and presenting data. Los Angeles: Sage.

Curdt-Christiansen, Xiao Lan. 2009. Invisible and visible language planning: Ideological factors in the family language policy of Chinese immigrant families in Quebec. Language Policy 8(4). 351-375.

Curdt-Christiansen, Xiao Lan. 2016. Conflicting language ideologies and contradictory language practices in Singaporean bilingual families. Journal of Multilingual and Multicultural Development 37(7). 694-709.

Curdt-Christiansen, Xiao Lan. 2018. Family language policy. In James W. Tollefson \& Miguel PérezMilans (eds.), The Oxford handbook of language policy and planning, 420-441. New York: Oxford University Press.

De Fina, Anna. 2003. Identity in narrative: A study of immigrant discourse. Amsterdam: John Benjamins.

Garrett, Paul B. \& Patricia Baquedano-López. 2002. Language socialization: Reproduction and continuity, transformation and change. Annual Review of Anthropology 31. 339-361. 
Goffman, Erving. 1963. Stigma: Notes on the management of spoiled identity. Englewood Cliffs: Prentice-Hall.

Heller, Monica, Sari Pietikäinen \& Joan Pujolar. 2018. Critical sociolinguistic research methods: Studying language issues that matter. New York: Taylor \& Francis.

Heugh, Kathleen \& Christopher Stroud. 2019. Diversities, affinities and diasporas: A southern lens and methodology for understanding multilingualisms. Current Issues in Language Planning 20(1). 1-15.

Hewitt, John P. \& Randall Stokes. 1975. Disclaimers. American Sociological Review 40(1). 1-11.

Horst, Cindy, Sónia Pereira \& Olivia Sheringham. 2016. The impact of class on feedback mechanisms: Brazilian migration to Norway, Portugal and the United Kingdom. In Oliver Bakewell, Godfried Engbersen, Maria Lucinda Fonseca \& Cindy Horst (eds.), Beyond networks: Feedback in international migration, 90-112. London: Palgrave Macmillan.

Johnsen, R. forthcoming. Multilingual adolescents and their families: Agency, identities and practice. Troms $\varnothing$ : The Arctic University of Norway, Ph.D. dissertation.

Kerfoot, Caroline \& Kenneth Hyltenstam (eds.). 2017. Entangled discourses: South-North orders of visibility. New York: Routledge.

King, Kendall. 2016. Language policy, multilingual encounters, and transnational families. Journal of Multilingual and Multicultural Development 37(7). 726-733.

King, Kendall \& Elizabeth Lanza (eds.). 2019. Ideology, agency, and imagination in multilingual families: An introduction [Special Issue]. International Journal of Bilingualism 23(3). 717-723.

King, Kendall \& Lyn Fogle. 2006. Bilingual parenting as good parenting: Parents' perspectives on family language policy for additive bilingualism. International Journal of Bilingual Education and Bilingualism 9(6). 695-712.

Kirsch, Claudine. 2012. Ideologies, struggles and contradictions: An account of mothers raising their children bilingually in Luxembourgish and English in Great Britain. International Journal of Bilingual Education and Bilingualism 15(1). 95-112.

Lanza, Elizabeth. 1997. Language mixing in infant bilingualism: A sociolinguistic perspective. Oxford: Oxford University Press.

Lanza, Elizabeth \& Rafael Lomeu Gomes. 2020. Family language policy: Foundations, theoretical perspectives and critical approaches. In Andrea C. Schalley \& Susana A. Eisenchlas (eds.), Handbook of home language maintenance and development: Social and affective factors, 153-173. Berlin \& Boston: De Gruyter Mouton.

Levon, Erez. 2017. Situating sociolinguistics: Coupland - Theoretical debates. Journal of Sociolinguistics 21(2). 272-288.

Lomeu Gomes, Rafael. 2018. Family language policy ten years on: A critical approach to family multilingualism. Multilingual Margins 5(1). 54-76.

Lomeu Gomes, Rafael. 2020. Talking multilingual families into being: Language practices and ideologies of a Brazilian-Norwegian family in Norway. Journal of Multilingual and Multicultural Development. https://doi.org/10.1080/01434632.2020.1788037.

Martin-Jones, Marilyn \& Deirdre Martin (eds.). 2017. Researching multilingualism: critical and ethnographic perspectives. London: Taylor \& Francis.

McNamara, Tim. 2015. The challenge of theory. Applied Linguistics 36(4). 466-477.

Melo, Glenda Cristina Valim de \& Juliana Tito Rosa Ferreira. 2017. Gender, race, and nationality orders of indexicality in two consumed objects during the 2014 World Cup. Revista Brasileira de Linguística Aplicada 17(3). 405-426. 
Mignolo, Walter D. 2000. Local histories/global designs: Coloniality, subaltern knowledges, and border thinking (Princeton studies in culture/power/history). Princeton, N.J.: Princeton University Press.

Mignolo, Walter D. \& Catherine E. Walsh. 2018. On decoloniality: Concepts, analytics, praxis. Durham, North Carolina: Duke University Press.

Milani, Tommaso M. \& Michelle M. Lazar. 2017. Seeing from the South: Discourse, gender and sexuality from southern perspectives. Journal of Sociolinguistics 21(3). 307-319.

Moustaoui Srhir, Adil. 2019. Making children multilingual: Language policy and parental agency in transnational and multilingual Moroccan families in Spain. Journal of Multilingual and Multicultural Development. https://doi.org/10.1080/01434632.2019.1621879 (accessed 19 August 2019).

Obojska, Maria Antonina. 2019. 'Ikke snakke norsk?' - Transnational adolescents and negotiations of family language policy explored through family interview. Multilingua. https://doi.org/10.1515/multi-2018-0058 (accessed 19 August 2019).

Obojska, Maria Antonina \& Judith Purkarthofer. 2018. 'And all of a sudden, it became my rescue': Language and agency in transnational families in Norway. International Journal of Multilingualism 15(3). 249-261.

Pájaro, Verónica. 2011. A Norwegian speaks Norwegian: An analysis of categorization and identity construction in narratives of Latin American migrants in Oslo. Oslo: University of Oslo MA Thesis.

Pájaro, Verónica. 2018. Who gets to pass? Performances of professional selves and language competences in job interviews in multilingual Norway. Oslo: University of Oslo PhD Dissertation.

Pennycook, Alastair. 2001. Critical applied linguistics: A critical introduction. Mahwah, N): Lawrence Erlbaum.

Pennycook, Alastair \& Sinfree Makoni. 2020. Innovations and challenges in applied linguistics from the global South. Abingdon and New York: Routledge.

Piller, Ingrid. 2001. Private language planning: The best of both worlds? Estudios de Sociolingüística 2(1). 61-80.

Pratt, Mary Louise. 1991. Arts of the contact zone. Profession 91, 33-40. https://www.jstor.org/ stable/25595.

Pujolar, Joan \& Isaac Gonzàlez. 2013. Linguistic ‘mudes’ and the de-ethnicization of language choice in Catalonia. International Journal of Bilingual Education and Bilingualism 16(2). 138-152.

Pulici, Carolina. 2014. Exclusivity or primacy of the rarest practices: The multi-territorial displacements in the socialization of São Paulo upper classes. Plural - Revista de Ciências Sociais 21(2). 47-76.

Purkarthofer, Judith. 2019. Building expectations: Imagining family language policy and heteroglossic social spaces. International Journal of Bilingualism 23(3). 724-739.

Purkarthofer, Judith \& Guri Bordal Steien. 2019. "Prétendre comme si on connaît pas une autre langue que le swahili": Multilingual parents in Norway on change and continuity in their family language policies. International Journal of the Sociology of Language. https://doi. org/10.1515/ijsl-2018-2005 (accessed 19 August 2019).

Santos, Boaventura de Sousa. 2014. Epistemologies of the South: Justice against epistemicide. Boulder: Paradigm Publishers.

Santos, Boaventura de Sousa. 2018. The end of the cognitive empire: The coming of age of epistemologies of the south. Durham, North Carolina: Duke University Press. 
Schieffelin, Bambi B., and Elinor Ochs, (eds.). 1986. Language socialization across cultures. Cambridge: Cambridge University Press.

Schwarcz, Lilia Moritz. 2019. Sobre o autoritarismo brasileiro [On the Brazilian authoritarianism]. São Paulo: Companhia das Letras.

Smith-Christmas, Cassie. 2017. Family language policy: New directions. In John Macalister and Seyed Hadi Mirvahedi (eds.). Family language policies in a multilingual world: Opportunities, challenges, and consequences, 23-39. New York: Routledge.

Soler, Josep \& Tim Roberts. 2019. Parents' and grandparents' views on home language regimes: Language ideologies and trajectories of two multilingual families in Sweden. Critical Inquiry in Language Studies. https://doi.org/10.1080/15427587.2018.1564878 (accessed 19 August 2019).

Souza, Ana. 2010. Migrant languages in a multi-ethnic scenario: Brazilian Portuguese-speakers in London. Portuguese Studies 26(1). 79-93. https://www.jstor.org/stable/41105332.

Souza, Ana. 2015. Motherhood in migration: A focus on family language planning. Women's Studies International Forum 52. 92-98.

Souza, Lynn Mario T. Menezes de. 2019. Glocal languages, coloniality and globalization from below. In Manuela Guilherme and Lynn Mario T. Menezes de Souza (eds.). Glocal languages and critical intercultural awareness: The south answers back, 17-41. New York: Routledge.

Statistics Norway. 2019. Population by immigrant category and country background. https:// www.ssb.no/en/befolkning/statistikker/innvbef (Accessed 16 August 2019).

Viveiros de Castro, Eduardo. 2004. Perspectival anthropology and the method of Controlled Equivocation. Tipití: Journal of the Society for the Anthropology of Lowland South America 2(1). 3-22. http://digitalcommons.trinity.edu/tipiti/vol2/iss1/1.

Zapponi, Marcela Barreto. 2015. Departures and arrivals: Motivations, experiences and expectations of Brazilian Immigrant Women in Norway. Trondheim: Norwegian University of Science and Technology MA Thesis. 